\title{
worldview
}

A JOURNAL OF RELIGION AND INTERNATIONAL AFFAIRS

\section{DANGEROUS REACTIONS}

Premier Khrushchev's performance at his final press conference in Paris, a British commentator has observed, "was betier anti-Soviet propaganda than any Western agency could have devised. It completely destroyed the popular image of the Soviet leader as a friendly, reasonable man of affairs . . . and substituted a frightening picture of brutal and malignant iarrogance." This image was not altered by Mr. Khrushchev's remarks at his June 3 press conference in Moscow. Here his personal abuse of President Eisenhower reached new depths of virulence and hysteria.

These developments have, of course, had practical effects in this country. President Eisenhower's televised report to the nation on the collapse of the summit conference was a model of restrained dignity in the face of crude provocation. But some other reactions have been less reassuring. Two in particular offer a distinct danger to the nation's political life-particularly in its approach to problems of the Cold War.

One of these reactions is the argument that for the sake of "unity" debate over the U-2 episode must be stopped, even before it has begun; the other is the suggestion that the worth of an American statesman, and his ability to deal with the Soviet challenge, can be measured by the attacks Mr. Khrushchev has made upon him.

These reactions (and they have been widely voiced in both parties during the past few weeks) suggest an alarming revival of the "treason" issue in American life. This is the issue that virtually cut off debate on major topics during the years of Senator Joseph McCarthy's power and reduced our political discussion to arguments over the "patriotism" of particular candidates. In such an atmosphere a dispassionate examination of issues was virtually impossible and policy tended to be a merely negative response to Communist pressure. If this were to happen again, as a result of $\mathrm{Mr}$. Khrushchev's conduct, the Soviet chief would have achieved a major victory over American life.
The fact is that never has a national debate over our policy in the Cold War been more necessary than it is now. We are entering upon a presidential election campaign in a year of great transition. Past policies must be reexamined and future policies suggested in an atmosphere free from that negative superpatriotism which chokes off discussion by suggesting (however subtly and indirectly) that to criticize American policy is to betrav America.

If we succumb to this insidious proposal, $\mathrm{Mr}$. Khrushchev will have succeeded more signifcantly than ever before in his campaign to divide and intimidate American opinion.

Premier Khrushchev has many faces and he plays many roles. What face he wears and what role he plays in any given crisis is perhaps determined as much by power struggles within the Kremlin and by pressures from Red China as by anything the United States can say or do. The Soviet leadership remains a mystery wrapped in an enigma. There can be no doubt, however, that our handling of the U-2 incident gave.Mr. Khrushchev an excuse, at least, for his present behavior.

It would be tragic indeed if, as a result of his behavior, we assigned the Soviet Premier yet another role: the manipulator of America's political affairs. A great nation, a mature nation, must resist the temptation merely to react, even to conduct as deplorable as Mr. Khrushchev's. It must freely debate great issues and formulate future policies on a basis more positive, more rational than this.

Notice: In keeping with the practice of most of America's journals of opinion, Worldview will suspend publication for one month during the summer. A combined July-August issue will appear toward the end of July. The regular monthly schedule will be resumed in September. As a result of this, current subscriptions will be extended for one month. 